\title{
Entrepreneurial Competencies and Business Success Among Women Entrepreneurs
}

Mohamad Hanif Baharudin, Nur Hazelin Mat Rusok, Nur Shaliza Sapiai, Siti Aswani Mohd Ghazali, Mohamad Sayuti Salleh

To Link this Article: http://dx.doi.org/10.6007/IJARBSS/v11-i2/8796

DOI:10.6007/IJARBSS/v11-i2/8796

Received: 03 January 2021, Revised: 27 January 2021, Accepted: 10 February 2021

Published Online: 23 February 2021

In-Text Citation: (Baharudin et al., 2021)

To Cite this Article: Baharudin, M. H., Rusok, N. H. M., Sapiai, N. S., Ghazali, S. A. M., \& Salleh, M. S. (2021). Entrepreneurial Competencies and Business Success Among Women Entrepreneurs. International Journal of Academic Research in Business and Social Sciences, 11(2), 302-310.

\section{Copyright: (c) 2021 The Author(s)}

Published by Human Resource Management Academic Research Society (www.hrmars.com)

This article is published under the Creative Commons Attribution (CC BY 4.0) license. Anyone may reproduce, distribute, translate and create derivative works of this article (for both commercial and non-commercial purposes), subject to full attribution to the original publication and authors. The full terms of this license may be seen at: http://creativecommons.org/licences/by/4.0/legalcode

Vol. 11, No. 2, 2021, Pg. 302 - 310

Full Terms \& Conditions of access and use can be found at http://hrmars.com/index.php/pages/detail/publication-ethics 


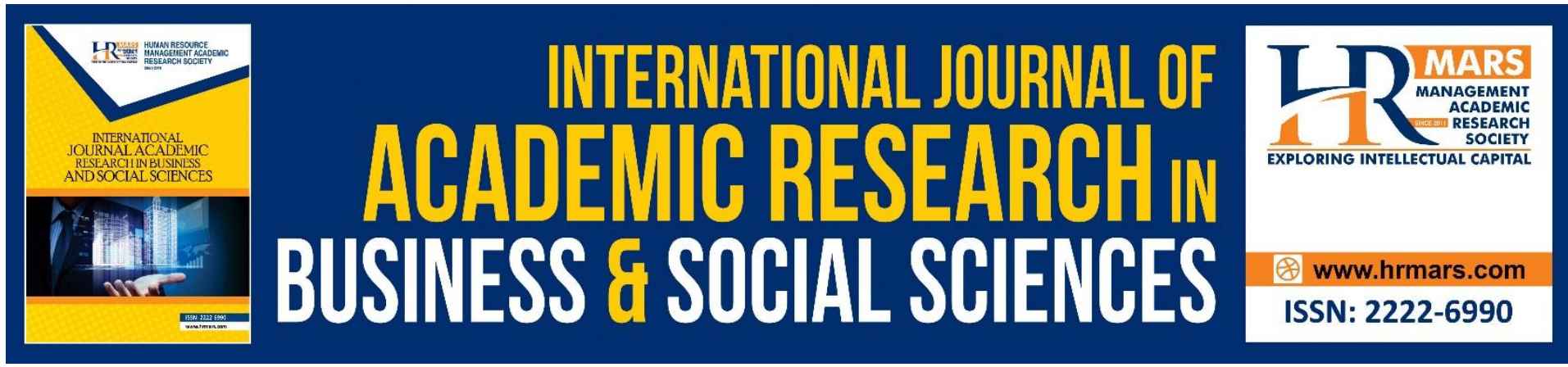

\title{
Entrepreneurial Competencies and Business Success Among Women Entrepreneurs
}

\author{
Mohamad Hanif Baharudin, Nur Hazelin Mat Rusok, Nur \\ Shaliza Sapiai, Siti Aswani Mohd Ghazali, Mohamad Sayuti \\ Salleh \\ Faculty of Business and Management, MARA University of Technology, Malaysia
}

\begin{abstract}
The Malaysian government's objective of wanting to establish rapid growth of women entrepreneurs is a high priority, while the long-term sustainability and survival of business are also given similar importance. Malaysian government actively promotes women's involvement in entrepreneurship with the aim of stimulating the country's economy. However, many women entrepreneurs, especially in developing countries, lack competencies. Thus, the present study aims to propose a model for women business success that aligns with entrepreneurial competencies It has utilised 6 dimensions of entrepreneurial competencies, which are: strategic competencies, commitment competencies, organizing competencies, relationship competencies, commitment competencies, opportunity competencies and conceptual competencies. Structural Equation Modeling (SEM) has been employed as the main statistical technique in this study. Overall, the study has found that only four of the independent variables (i.e. elements of entrepreneurial competencies), namely relationship, opportunity, organizing and commitment competencies have significant relationships with women's business success. The remaining 2 domains, strategic competencies and conceptual competencies have revealed to be not significant. The findings are likely to be useful to SMEs, as they have highlighted the necessity of focusing on training to yield increased effectiveness. The model from this study will also further contribute towards the development of literature review related to the favourable outcome for women entrepreneurs.
\end{abstract}

Keywords: Competencies, Women Entrepreneurs

\section{Introduction}

Women play as an important role for the economic development of families and communities. However, such development and growth in developing countries have generally been hindered by various barriers, such as unemployment, low family income, poverty and inequity. Such obstacles have prompted a majority of these women to become involved in business activities so as to support their household. According to Ekpe, Norsiah, \& Razli (2010), their study on the roles of microfinance factors on women entrepreneurs' performance in Nigeria has concluded that women involvement in entrepreneurship is the 
best strategy towards alleviating poverty in Nigeria. This is explained by how women are the people hit hardest in unemployment and poverty.

The Malaysian government are in recognition of potential contribution to the country's economy with the commencement of woman participation in business, despite the low rate of women's entrepreneurship (Rozita, Rozita, Nur Syakiran Akmal, \& Zalinah, 2015). This can be substantiated by the different and myriad forms of support and assistance provided by the administration to nurture the sector. Developing countries, which includes Malaysia, will undoubtedly benefit from an unlimited women's access to microfinance; it empowers them into significantly contributing towards family income, the household's well-being and more forward changes from gender inequality (Biswas \& Hassan, 2009). This is paralleled by a study by Tata \& Prasad (2008), which has revealed that women micro-enterprises' performances can be affected elements like member bonding, motivation and opportunities of engaging in collaborative exchanges, appropriate training and mandatory saving. Therefore, this has substantiated the importance of microfinance programs in pushing forward women entrepreneurship, especially in developing countries bogged by limited access of credit and other opportunities.

As per the $10^{\text {th }}$ and $11^{\text {th }}$ Malaysia Plan, the government has outlined their focus for women empowerment for the purpose of improved economic contribution via entrepreneurship. This can be reflected by the projected rapid growth of the number of women entrepreneurs becoming involved and succeeding in their respective businesses (Baharudin et al, 2020). In the $10^{\text {th }}$ Malaysia Plan, efforts to improve entrepreneur's confidence, skills, training have been undertaken by introducing special assistance schemes so as to spur women to triumph past challenging circumstances and engage in entrepreneurial activities. According to the 2015 Female Entrepreneur Index report on analyzing the condition that foster high potential female entrepreneurship 77 countries, it was showed that " 61 percent of the countries score below $50 \%$ out of $100 \%$ including Malaysia; scores 39.2 percent (below $50 \%$ ) and the authors suggested women entrepreneurs need to improve entrepreneurial competencies" (as stated by Terjesen, 2015). Because of that, women entrepreneur in Malaysian need to improve entrepreneur competencies that women believe that they possess the required knowledge and skills in running business. This support by Nor Asiah, Muhamad Azrin, \& Che Aniza (2014) which found that most of the low income women who are involved in micro enterprises (MEs) in Malaysia have low business sustainability due to business competencies. Therefore, this study focuses on women entrepreneurial competencies that influence the women entrepreneurs business success. The study will use 6 domain of entrepreneurial competencies which had been developed by Man (2002). The dimensions consist of strategic, commitment, organizing, relationship, commitment and conceptual.

\section{Literature Review}

Bird (1995, p.51) has previously insisted regarding the "need for a suitable theory of entrepreneurial competencies. The meaning and related theory of competency can be applied from education and management literatures so as to expand them to be representative of what successful entrepreneurs do". Bird (1995) has also highlighted entrepreneur's competencies as the "underlying characteristics (i.e. specific skills, traits, motives, self-images, social roles and knowledge) contributory towards growth, survival and success". The theory has been subsequently adapted and extended by many researchers, such as (Inyang and Enuoh, 2009; Mitchelmore and Rowley, 2010, DeTienne and Chandler, 
2004; Man et al., 2002). Man et al. (2002) in particular has adapted the theory by creating the domain for entrepreneurial competencies, specifically on for Hong Kong SME firms in services sector towards business success. The resulting six domains are: (1) strategic competencies, (2) commitment competencies, (3) opportunity competencies, (4) relationship competencies, (5) conceptual competencies, and (6) organizing competencies. The domains formulated by Man et al. (2002) have been chosen due to various reasons, such as: (i) they have been obtained from comprehensive studies (Chandler \& Jansen, 1992; Baum, 1995; Georgellis et al., 2004; Martin \& Staines, 1994; McClelland, 1987; Snell \& Lau, 1994; (ii) data validating the model are located in Asia instead of American or European contexts in other studies; and (iii) the resulting two elements of entrepreneurial competencies obtained (Man et al., 2002). The first element has emphasized on the entrepreneur's background (i.e. attitudes, traits, self-image, personality and networks), whereas the second element can be attained in work or via "practical or theoretical learning" (i.e. knowledge, skills, and experience).

Finally, many works have focused on the impacts of "entrepreneurial competencies" in the context of business growth and success (Colombo \& Grilli, 2005) and firm's performance and competitiveness (Man et al., 2002). Acquisition of the competencies is influential towards the strive for achievements, but despite the focus on the topic, gaps in knowledge are still present (Man et al., 2002; Mitchelmore \& Rowley, 2010). A section that is notably neglected is primarily regarding issues associated with competencies development processes, in the context of women entrepreneurs.

\section{Methodology}

The research methodology applied in this work, which is the quantitative method. The research design has been utilized to measure the variables accordingly, which are entrepreneurial competencies and women business success. Furthermore, the probabilitysampling method of stratified sampling has been utilized to obtain appropriate sample and subsequently subjected for data collection processes. The collection processes have encompassed the literature view and distribution of self-administered questionnaires. Subsequently, all statistical techniques used for this study have also been explained and verified, alongside the use of other inferential statistics, other than the descriptive statistics (i.e. frequency distribution, mean, and standard deviation). The statistical tests used to test the research questions and hypotheses in particular are the Regression Analysis. Based on the population of women entrepreneurs in Kelantan, Malaysia, the sample size for this study has been set to 377 respondents. The data obtained has been analyzed using Statistical Package for Social Science (SPSS) for Windows and Structural Equation Modeling (SEM) via AMOS.

\section{Analysis}

\section{Assessment of the Structural Model}

SEM is conducted for the purpose of testing regression pathways present between dependent and independent variables. It has been run and the resulting fit indices have been presented in Table 1 below: 
Table 1: Structural Model Fit Indices

\begin{tabular}{|l|l|}
\hline Model Fit Indices & Value \\
\hline$\chi^{2}$ & 960.857 \\
\hline$\chi^{2} / \mathrm{df}$ & 2.189 \\
\hline RMSEA & 0.055 \\
\hline CFI & 0.944 \\
\hline TLI & 0.936 \\
\hline
\end{tabular}

The results have indicated no necessity for model re-specification as all indices have displayed the required level of significance. The ratio of $\chi^{2} / \mathrm{df}$ is within the acceptable range of 1-3 ( $\left.\chi^{2} / d f=2.189\right)$ (Musteen, Datta, \& Butts, 2014). Furthermore, the RMSEA value (0.055) has been deemed satisfactory, as per Browne and Cudeck's (1992) suggested value to be equal or lower than $(\leq)$ 0.08. Meanwhile, the incremental fit indices, Tucker-Lewis index (TLI) and comparative fit index (CFI) have both scored higher than the acceptable values of $\geq$ 0.90 (Bagozzi \& Yi, 1988).

\section{Result of Path Analysis}

To examine the structural paths, $z$-value has been applied to the regression significance (beta coefficient). It will only be considered as statistically significant if the z-value (C.R.) is bigger than +/- 1.965 at $5 \%$ significance level, or bigger than +/- 2.587 at a $10 \%$ significance level, or bigger than $+/-3.313$ at a $1 \%$ significance level (Degree of freedom=439). As this study has opted for $5 \%$ significance level, the $z$-value must be greater than $+/-1.965$. Table 2 below has subsequently displayed the parameter estimates, standard errors, critical ratios and significance values for all paths present in the model.

Table 2: Parameter Estimates, Critical Ratios and Significance Value of the Model

\begin{tabular}{lllllll}
\hline Path Analysis & & Estimate & S.E. & $\begin{array}{l}\text { C.R.(z- } \\
\text { value) }\end{array}$ & Results & Decision \\
\hline SF & OP & 0.277 & 0.076 & 3.639 & 0.001 & Supported \\
SF & OG & 0.169 & 0.054 & 3.158 & 0.002 & Supported \\
SF & ST & 0.010 & 0.044 & -.225 & 0.822 & Not \\
SF & RL & 0.490 & 0.124 & 3.969 & 0.001 & Supported \\
SF & CT & 0.112 & 0.054 & 2.083 & 0.037 & Supported \\
SF & CP & 0.001 & 0.072 & .018 & 0.986 & Sot \\
\hline & & & & & &
\end{tabular}

$\mathrm{SF}=$ Success factor, $\mathrm{OP}=$ Opportunity, $\mathrm{OG}=$ Organizing, $\mathrm{ST}=$ Strategic, $\mathrm{RL}=$ Relationship, $\mathrm{CT}=$ Commitment, $\mathrm{CP}=$ Conceptual

\section{Results of Hypotheses Testing}

After analyzing the measurement and structural part of SEM, the next focus will be put on the resulting statistical analysis of the hypotheses. There are 6 hypotheses have been developed, as seen below:

$H_{1}=$ Opportunity Competencies has positive relationship with Business Success among Women Entrepreneur 
It has been hypothesized that there is a positive and significant relationship between opportunity competencies and business success. This view is supported in the current research ( $\beta, z$-value and $p$-value). With a $z$-value of 3.639 , it can be proven that the direct relationship between opportunity competencies and business success is significant, thus supporting the hypothesis as well as the extant literature reporting them. Chandler and Jansen (1992) have previously highlighted the capability of recognizing and taking advantage of opportunities as a crucial entrepreneurial role. It requires competence in identifying opportunities, actively seeking new ones, and developing them. Besides, Man et al. (2002) has outlined the positive impacts of such competencies towards SMEs' business success, due to its positive relationship with SMEs' business success.

$\mathrm{H}_{2}=$ Organizing Competencies has positive relationship with Business Success among women entrepreneur

It has been hypothesized that there is a positive and significant relationship between organizing competencies and business success. The pathway between them has shown significance due to a $z$-value of 3.158, which has further supported the hypothesis and extant literature in this study. McClelland (1987) has described "efficiency orientation", "concern for high quality of work", and "monitoring" as necessary competencies in the management of different functional areas in a firm to ensure efficient operations. Furthermore, Man et al. (2002); Hazlina (2007) have also highlighted the positive relationship between organizing competencies and SMEs' business success.

$\mathrm{H}_{3}=$ Strategic Competencies has positive relationship with Business Success among women entrepreneur

Strategic competencies have been found as predictor not significant for business success. The analysis has reported a $z$-value of 0.822 , which is less than the acceptable significant value of 1.965 . It has paralleled with the study by Fatimah et al. (2014), has concluded that the relationship between strategic thinking and business success is not significant as women entrepreneurs generally lack in knowledge and experiences. The specific competencies call for them to me visionary when it comes to their businesses, have clear goals, and formulate strategies to achieve such goals.

$\mathrm{H}_{4}=$ Relationship Competencies has positive relationship with Business Success Women Entrepreneur

This study has shown that relationship competencies have a positive and significant relationship with business success, with a z-value of 3.969 when compared to the significant and accepted value of 1.965. As shown by Man et al. (2002) and Noor Hazlina, A. (2007), relationship competencies have displayed a positive and significant impact toward SMEs' business success. Therefore, women entrepreneurs in Malaysia are capable of cooperating, trusting, making contacts and connections, persuading, communicating and utilizing their interpersonal skills (Man et al., 2002).

$\mathrm{H}_{5}=$ Commitment Competencies has positive relationship with Business Success among Women Entrepreneur

The z-value for commitment competency is 2.083, which has exceeded the significant acceptable value of 1.96. Therefore, it reflects of a positive significant relationship with business success, which is seen in their drive to proceed forward with their respective ventures. Thus, as summarized by Man et al. (2002), commitment competencies have a positive relationship with SMEs' business success, which will be reflected in women entrepreneurs' commitment, determination, dedication, and proactivity towards their responsibilities and duties. 
$\mathrm{H}_{6}=$ Conceptual Competencies has positive relationship with Business Success among Women Entrepreneur

The literature has highlighted a positive and significant relationship between conceptual competencies with business success. However, this study has shown the opposite as the zvalue of 0.018 is well below the value of significant acceptable level of 1.96. Therefore, women entrepreneur are not associated with capabilities of cognitive and analytical thinking, creativity, and innovativeness; it has paralleled various previous works (Fatimah, Aznarahayu, \& Nasina, 2014; Haron et al., 2010).

\section{Conclusion}

The model structure has discovered that only four of the independent variable (elements of entrepreneurial competencies), namely relationship, opportunity, organizing and commitment competencies to have significant relationship towards women business success respectively. Based on results, it can be concluded that the model entrepreneurial competencies adopted is fit for women entrepreneurs. There are two variables show not significant, namely strategic and conceptual competencies. It paralleled with Fatimah et al. (2014) has previously concluded on "Women rural in Malaysia: Drive to success" that the relationship between strategic thinking and business success is not significant. This is due to women entrepreneur lacking the experiences in developing vision and strategy, planning, selling ideas, and setting goals and standards. This can be explained as their lack of capability to engage in cognitive and analytical thinking and being creative and innovative. The researcher concluded that women entrepreneurs in rural area are not competent conceptually due to insufficient knowledge and training. Therefore, the findings are likely to be useful to SMEs, with extra focus on the need for training so as to improve effectiveness. The government and other associated agencies should also consider providing more training to increase entrepreneurial competencies for women entrepreneurs.

\section{Theoretical and Contextual Contribution}

The results obtained from this study have revealed several significant theoretical and practical implications such as this study can contributed in adding new knowledge to the field of entrepreneurship, especially among women entrepreneurs. This study has successfully that women's success in SMEs requires acting as key player. Therefore, this study is in support of a competency approach that will allow understanding the women business success in SMEs. Secondly, this study has aimed to develop a viable multidimensional construct of entrepreneurial competencies, through a systematic process of empirical verification and testing using data from the women entrepreneurs in SMEs operating in Malaysia. Besides, result obtained in analysis show two (2) variables were not significant, conceptual and strategic competency. Therefore, the findings are likely to be useful to SMEs, with extra focus on the need for training so as to improve effectiveness. The government and other associated agencies should also consider providing more training to increase these competencies for women entrepreneurs.

\section{Acknowledgements}

My deepest appreciation goes to my parents and beloved family for supporting morally. Their kind understanding, courage, love and personal attention towards the completion of this paper will not forget. Their supports have enabled me to achieve this milestone. 


\section{References}

Bagozzi, R. P., \& Yi, Y. (1988). On the Evaluation of Structural Equation Models. Journal of the Academy of Marketing Science, 16(1), 74-94.

Baum, J. R., Locke, E. A., \& Smith, K. G. (2001). A Multidimensional Model of Venture Growth. Academy of Management Journal, 44(2), 292-303.

Bird, B. (1995). Toward a theory of entrepreneurial competency. Advances in Entrepreneurship, Firm Emergence and Growth, 2(1), 51-72.

Biswas, K., \& Hassan, K. (2009). A Test of Association between Working Hour and Work Family?Conflict:?A Glimpse on Dhaka's Female White Collar Professionals. International Journal of Business and Management, 4(5), 27.

Browne, M. W., \& Cudeck, R. (1992). Alternative ways of assessing model fit. Sociological Methods \& Research, 21(2), 230-258. http://doi.org/0803973233

Chandler, G. N., \& Jansen, E. (1992). The founder's self-assessed competence and venture performance. Journal of Business Venturing, 7(3), 223-236.

Colombo, M. G., \& Grilli, L. (2005). Founders' human capital and the growth of new technology-based firms: A competence-based view. Research Policy, 34(6), 795-816.

de Burca, S., Fynes, B., \& Brannick, T. (2006). The moderating effects of information technology sophistication on services practice and performance. International Journal of Operations \& Production Management, 26(11), 1240-1254. http://doi.org/10.1108/01443570610705845

DeTienne, D. R., \& Chandler, G. N. (2004). Opportunity identification and its role in the entrepreneurial classroom: A pedagogical approach and empirical test. Academy of Management Learning \& Education, 3(3), 242-257.

Ekpe, I., Norsiah, B. M., \& Razli, C. R. (2010). The Effect Of Microfinance Factors On Women Entrepreneurs' Performance In Nigeria: A Conceptual Framework. International Journal of Business and Social Science, 1(2).

Fatimah, H., Aznarahayu, R., \& Nasina, M. D. (2014). Rural Women Entrepreneurs in Malaysia: What Drives Their Success? International Journal of Business and Management, 9(4), 10-22. http://doi.org/10.5539/ijbm.v9n4p10

Georgellis, Y., Joyce, P., \& Woods, A. (2000). Entrepreneurial action, innovation and business performance: the small independent business. Journal of Small Business and Enterprise Development, 7(1), 7-17.

Haron, H., Ismail, I., Yahya, S., Khalid, S. N. A., \& Ganesan, Y. (2010). Cases of successful Malaysian small and medium enterprises (SMEs): Does business advisory services help? Malaysian Institute of Accountants Funded.

Inyang, B. J., \& Enuoh, R. O. (2009). Entrepreneurial Competencies: The Missing Links to Successful Entrepreneurship in Nigeria. International Business Researcrch, 2(2), 62-71. Retrieved from http://ccsenet.org/journal/index.php/ibr/article/download/1120/1122

Krejcie, R. V, \& Morgan, D. W. (1970). Determining sample size for research activities. Educational and Psychological Measurement, 30, 607-610.

Man, T., Lau, T., \& Chan, K. F. (2002). The competitiveness of small and medium enterprises. A conceptualization with focus on entrepreneurial competencies. Journal of Business Venturing, 17(2), 123-142.

Martin, T. G. (1999). Socio-economic impact of microenterprise credit in the informal sector of Managua, Nicaragua. Retrieved January 21, 2009, from http://scholar.lib.vt.edu/thesis 
McClelland, D. C. (1973). Testing for competence rather than for" intelligence." American Psychologist, 28(1), 1

Mitchelmore, S., \& Rowley, J. (2010). Entrepreneurial competencies: a literature review and development agenda. International Journal of Entrepreneurial Behavior \& Research, 16(2), 92-111.

Musteen, M., Datta, D. K., \& Butts, M. M. (2014). Do International Networks and Foreign Market Knowledge Facilitate SME Internationalization? Evidence from the Czech Republic. Entrepreneurship Theory and Practice, 38(4), 749-774.

Noor Hazlina, A., Hasliza, A. H., \& Siti Rohaida, M. Z. (2010). Is entrepreneurial competency the silver bullet for SME success in a developing nation? International Business Management, 4(2), 67-75.

Nor Asiah, O., Muhamad Azrin, N., \& Che Aniza, C. W. (2014). Entrepreneurial Training of LowIncome Women Micro Enterprises in the Service Sector in Malaysia: Understanding the Problems and Challenges. Journal of Social and Development Sciences, 5(4), 245-257.+

Rozita, A. M., Rozita, A., Nur Syakiran Akmal, I., \& Zalinah, A. (2015). Women and Entrepreneurship: An Overview of Women Entrepreneurship Programs in Malaysia. Special Issue on Social Entrepreneurship, 11, 15-28.

Snell, S. A., \& Dean, Jr., J. W. (1992). Integrated manufacturing and human resource management: A human capital perspective. Academy of Management Journal, 35(3), 467-504. http://doi.org/10.2307/256484

Tata, J., \& Prasad, S. (2008). Social capital, collaborative exchange and microenterprise performance: The role of gender. International Journal of Entrepreneurship and Small Business, 5(3-4), 373-388.

Tehseen, S., Sulaiman, S., Ramayah, T., \& Gadar, K. (2015). An Intra-Cultural Study of Entrepreneurial Competencies and SMEs Business Success in Whole Sale and Retail Industries of Malaysia : -A Conceptual Model. Review Of Integrative Business Research and Economics, 4(3), 33-48.

Zainudin, A. (2010). Research methodology for business and social science. Shah Alam: Universiti Teknologi Mara Publication Centre (UPENA). 